\title{
The Effect of Guided Inquiry Learning Model on Process Skills Science and Students' Higher-Level Thinking Skills on Heat and Transfer Themes of Class V SD Negeri 104260 Melati
}

\author{
Ahmad Marwan', Has ruddin'2, Yusnadi ${ }^{3}$ \\ ${ }^{1}$ Postgraduate Program in Universitas Negeri Medan, Indonesia \\ ${ }^{2,3}$ Universitas Negeri Medan, Indonesia
}

\begin{abstract}
This research aims to determine the effect of guided inquiry learning models on science process skills and higher order thinking skills on the theme of heat and its displacement in grade V SD Negeri 104260 Melati. The research instrument included observation of science process skills and tests of higher order thinking skills. This study uses the analysis of the Independent Sample Test (t test).The average value of science process skills in the guided inquiry class was 81.62 and the direct instruction learning model class was 79.02. A significant influence on students' science process skills in the learning process on the theme of heat and its displacement, with a score of tcount (2.384)> ttable (2.004) for $n=56, \alpha=0.05$ and sig. 2 tailed $(0.021)<\alpha=0.05$, so that $H_{0}$ rejected. then $\mathrm{Ho}$ was rejected and Ha accepted. The average value of high-order thinking skills in the guided inquiry class is 75.57 and in the class of direct instruction learning model. A total of 67.43. The results of the analysis of high-order thinking skills have tcount (3.597)> ttable (2.004) for $n=56, \alpha=0.05$ and sig. 2 tailed (0.001) $<\alpha=0.05$, so that Horejected and Ha accepted. Guided inquiry learning model affects science process skills and high-order thinking skills of students on the theme of heat and its displacement in grade V SD Negeri 104260 Melati.
\end{abstract}

Keywords

guided inquiry

learning model;

science process skills;

higher level thinking

ability

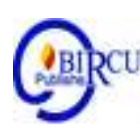

\section{Introduction}

Changes in students can be achieved if there is a way that can be applied in learning. The method used to design a lesson is to prepare an appropriate learning model and be able to bring students to be actively involved. The teacher creates a learning atmosphere that is more active, innovative, and fun so that students are interested in following the lessons delivered. This is in accordance with the teacher's duties according to Neolaka (2017: 19) which states that teachers must create a comfortable learning atmosphere for students. The teacher is the spearhead of the ongoing teaching and learning process, so that the teacher has an important role as a source of learning in the transformation of the value of science (Iskandar in Kuncoro, 2020).

Based on the results of observations of student activities carried out at SD Negeri 104260 Melati, it is known that the guided inquiry learning model has not been implemented there. so that the data obtained on students' high-order thinking skills is lacking. Guided inquiry learning model is very good for improving students' higher order thinking skills compared to conventional learning models such as expository. Learning also rarely provides opportunities for students to understand the phenomena around them 
based on the concepts being learned and vice versa in the lessons of science concepts. Teachers in the teaching and learning process are more oriented towards the material listed in the curriculum and textbooks.

Teacher centered learning is no longer suitable for student development. Studentcentered learning is a way that can develop student abilities. The teaching method used by a teacher is one of the important factors that affect student learning outcomes. The use of guided inquiry learning models will make students more interested in what is conveyed by a teacher. Students will carry out learning by observing the experiments being carried out and looking for solutions according to the stages contained in the student worksheets.

In the learning process, it should encourage students to develop higher thinking skills. This is constrained due to limited time and space, but information in learning must still be conveyed to students. Time limitations occur due to the absence of careful planning taking into account students' initial abilities. The science learning process carried out by the teacher is only for memorizing information, so that students are expected to remember various information without being required to understand the information received to relate to everyday life.

Based on observations made at SD Negeri 104260 Melati in grade V, teachers teach science subjects using direct learning provided by the teacher, but students have not been trained to discover the concept of learning science by themselves. Guided inquiry learning has not been taught by the teacher because it does not fulfill how to teach science by using the guided inquiry learning model. The assessment aspect has not used process skills as a result of learning. In this activity, it is seen that the teacher explains the material in the book, while experiments or experiments on science lessons have not been carried out in front of the class.

Based on the results of observations on the learning process that has been carried out on a class Va teacher at SD Negeri No. 104260 Melati shows that students have not been directly involved in the activities of the learning process and the assessment of science process skills that the teacher lacks training, this can be seen in every science learning process whose activities are only taking notes and ending with giving questions. The learning outcomes obtained are only based on this knowledge which is in the book, namely in the form of questions, while the assessment of science process skills has not been carried out. In learning activities carried out by the teacher, participants only pay attention and observe what the teacher says. After the learning activity is complete the teacher makes conclusions and checks the learning outcomes of students. The learning outcomes of students who do get a score that is less than the KKM. The IPA KKM set by the teacher is 70. Based on the KKM grade, students in class Va who scored $<70$ were 24 people while those who received grades> 70 were 8 people. The questions given are still using questions that explore the level of understanding and remembering.

Problems in science learning, students are still provided with notes and assignments from the teacher but students cannot understand the lesson, class V teachers in presenting science learning materials only use conventional methods, namely the lecture method, question and answer method, assignments, demonstrations and exercises without involving students 'activeness in it, so that it makes students feel bored, does not feel interested in learning or students' learning motivation becomes low, and students will quickly forget the learning material they have just learned. In the group learning that is carried out, the teacher looks tired because he has to teach the subject matter repeatedly to different groups. 
Science is an important subject because it is included in the lessons tested in the National Standard School Examination (USBN). The USBN has questions that require students to think at a high level. The problems faced by these schools can improve the learning process in order to facilitate the implementation of the 2013 curriculum which requires students to have high-level thinking skills. Its implementation must be monitored and evaluated to find out how far the curriculum has been implemented so that later things that hinder the 2013 curriculum can be overcome and progress. Another problem is that the teacher still does not understand how to apply science process skills to students on the grounds that there are too many aspects measured in learning along with the number of students who will be observed one by one so that the teacher feels the burden is too heavy to carry out the learning. For that we need a teacher who can guide students by fostering student personalities so that they have good character based on the knowledge they have received (Waluyandi, 2020). The teacher can use student responses as an opportunity to evaluate their readiness to learn more deeply, and introduce new concepts that are appropriate and challenge their thinking (Mindayani, 2019). The 2013 curriculum is a new curriculum that requires development for improvement in the future.

Based on the background, it is considered important to conduct research on a model that is considered suitable and able to provide understanding for students so that learning becomes meaningful. Guided inquiry learning model is a learning model that is very relevant in improving higher-order thinking skills. Guided inquiry learning models need to be taught so that together with science process skills can train and improve higher-order thinking skills properly.

\section{Review of Literatures}

\subsection{Guided Inquiry Learning Model (Guided Inquiry)}

According to Garton (in Yani, 2019: 84-85) giving signs for guided inquiry learning, namely that you must always ask questions that provoke students' curiosity (question), the learning plan must be designed to involve students in the guided inquiry process or search. (student engagement), working together and discussing to answer questions (cooperative interaction), using a variety of learning resources (variety of resources), using performance appraisals during the inquiry process (performance evaluation). The definition of inquiry according to Hamdayana (2017: 31) states that inquiry is a learning process based on search and discovery through systematic thinking.

Based on this opinion, it can be stated that inquiry is a learning model where the teacher guides students so that students can be active in the learning process in the classroom as well as a comfortable classroom atmosphere. According to Hamdayana (2017: 31) The inquiry learning model is a series of learning activities that emphasize critical and analytical thinking processes to seek and find answers to a question in question. Guided inquiry is a learning that emphasizes students to try to convey their ideas and ideas based on observations with guidance from the teacher. the teacher guides students based on the activity steps designed in the learning activities.

The main purpose of learning using the inquiry learning model is to enable students to develop knowledge and thinking skills by asking questions and getting answers on the basis of their curiosity. Students are required to play a very dominant role in the learning process because the 2013 curriculum learning process is no longer teacher-centered. The teacher acts as a facilitator who guides students in achieving an understanding of the material presented by the teacher. The teacher is also a guide in learning activities so that learning goes according to the steps that have been planned. 
One of the types of inquiry learning models that are suitable to be applied in elementary schools is the guided inquiry learning model. The guided inquiry learning model was chosen on the grounds that the guided inquiry learning model provides a better direction to students. Students who are not ready to solve problems in science lessons are due to a lack of experience and knowledge. There are several principles that must be considered in implementing the inquiry learning model, namely; (1) Oriented to intellectual development; (2) the principle of interaction; (3) the principle of asking; (4) The principle of learning to think; and (5) the principle of openness (Nurdiansyah, 2016: 43).

\subsection{The Nature of Science Process Skills}

Science Process Skills is a learning that emphasizes the learning process, activities and creativity of students in obtaining knowledge, skills, values and attitudes and can apply them in everyday life. Science process skills can be interpreted as the ability to carry out actions in learning science so as to produce concepts, principles, laws and facts. The concepts, principles or theories that have been discovered and developed will solidify an understanding of these process skills. According to Indrawati in Susanto (2016: 9-10) basic process skills consist of several parts: (1) observing; (2) classify / classify; (3) measure; (4) communicate; (5) interpreting the data; (6) predict; (7) using tools; and (8) conducting experiments.

According to Indrawati (Trianto, 2010: 144) states that science process skills are all directed scientific skills in it training steps to find something through experiments and experiments. Science process skills are not only given to students at the primary and secondary levels and even in tertiary institutions. The training of students in using science process skills makes it easier to apply science concepts in everyday life.

Based on the above definition, it can be stated that science process skills are all skills used to obtain and study various information about natural phenomena, especially those in the environment around students. Through science process skills, students can learn about science as scientists do such as observing, interpreting, predicting, classifying, planning, using tools and carrying out research and communicating the findings of Tawil, et al. (2014: 11).

\subsection{Higher-Order Thinking Skills}

High-order thinking skills in Bloom's Taxonomy are a sequence of levels of thinking (cognitive) from low to high levels. In the cognitive domain, HOTS is at the level of analysis, evaluation, and creation. Ministry of Education and Culture Directorate General of Primary and Secondary Education (2014: 13) Higher order thinking skill is the ability to recall information (recall) and more assessment measures the ability which consists of transferring one concept to another, processing and applying information, looking for links from a variety of different information, use information to solve problems, examine ideas and information critically.

As a basis for knowing the realm of higher order thinking skills according to Yani (2019: 82) is the cognitive domain of Bloom, Anderson, and Krathwoll and the division of cognitive levels into LOTS (C1, C2, and C3) and HOTS (C4, C5, and C6) ; High-level thinking skills as Critical and Creative Thinking are known as FRISCO thinking stages (Focus, Reason, Inference, Situation, Clarity, Overview), and 21st Century thinking skills known as 4C (Creativity, Critical Thinking, Collaboration, Communication).

Higher-order thinking skills are efforts that must be made by individuals who have been appointed to complete a predetermined goal critically, creatively, and can solve 
problems. According to Sofyan (2019: 1) the 2013 curriculum considers that HOTS (Higher Order Cognitive Thingking Skill) is a strategy that can be applied or used to be able to answer problems from the impact of globalization and national education in order to adapt to the future and the international world.

Based on the above opinion it can be stated that the application of the actions that must be taken by individuals who have been appointed to complete a predetermined goal, the application of higher-order thinking skills is not just knowledge to be achieved, but a planned activity and to achieve goals. learning. Higher order thinking skills need to be trained since elementary school so that students are trained to think scientifically. Higher order thinking skills are not only a way of thinking but also processing and analyzing information and solving problems.

\section{Research Methods}

This research was conducted at SD Negeri 104260 Melati, Serdang Bedagai Regency. This research will be conducted from January 4, 2021 to January 28, 2021. The population in this study were all fifth grade students of SD Negeri 104260 Melati in the academic year 2020/2021 which consisted of 2 classes, namely the Va class totaling 28 people and the $\mathrm{Vb}$ class totaling 28 people. with a total of 56 students. The class that is taught using the guided inquiry learning model becomes the experimental class, namely the $\mathrm{Va}$ class, while the $\mathrm{Vb}$ class which uses the direct instruction learning model becomes the control class. This type of research is a quasi experimental method with a pretestposttest control group design research design. This research will be conducted in 3 stages which include planning, implementation, and the final stage. There are two main instruments used, namely, higher order thinking skills tests and classroom observations based on science process skills. Higher order thinking skills tests are given to measure the level of students' understanding of the concepts in the topic being taught. Observation of the implementation of learning is used to complement the research data. The test instrument in this study used an objective test instrument in the form of multiple choices with four choices, namely, a, b, c and d as many as 30 questions. This test is structured based on the indicators to be achieved. The instrument used to capture data in this study is in the form of a test description. The existence of instruments in research aims to answer hypotheses or problem formulations. The test requirements that are ready to use need to know the validity, reliability, difficulty index, and the difference index. The data analysis technique includes the prerequisite test of the hypothesis and hypothesis testing. Data analysis techniques for hypothesis testing are carried out in several stages. Before testing the hypothesis, it is necessary to carry out several statistical prerequisite tests to determine the statistical formula to be used in testing the hypothesis. The normality test aims to determine whether the collected data is normally distributed or not. If the test is normal, the results of statistical calculations can be generalized to the population. The normality test was carried out using the SPSS 26 windows. Student data was obtained based on a normal distribution if the probability or significance value of the Kolmogorov-Smirnov Test> 0.05 .

\section{Discussion}

\subsection{The Effect of Guided Inquiry Learning Model on Science Process Skills}

Based on hypothesis testing in the experimental class and the control class using the t-test, it shows that there are significant differences in results between the experimental 
class and the control class. The results of the research data analysis showed that the average score of science process skills using the guided inquiry learning model was 81.64 and the direct instruction learning model was 79.04. The results obtained from the calculation of the two groups of data science process skills have a score of tcount 2.384)> $t$ table (2.004) for $\mathrm{n}=56$ people, $\alpha=0.05$ and sig. 2 tailed $(0.001)<\alpha=0.05$, so that $\mathrm{H}_{0}$ rejected. The experimental class and the control class have different levels of science process skills.

The guided inquiry learning model as one of the learning models that is highly recommended in the 2013 curriculum is the right choice to improve the learning process and improve student skills and abilities. This is because basically the guided inquiry learning model involves students in the transfer of knowledge and skills through the discovery process with the questions that have been given. Guided inquiry learning model is a learning model that demands creative teachers.

Science process skills in this study have six indicators that must be carried out at each step of learning to observe, namely: observation (observation), predicting (prediction), asking questions, using tools / materials, communicating and conducting experiments. Guided inquiry learning model is a learning model that supports science process skills. This learning model can train students to write the results of their group discussions into worksheets systematically so that students will better understand the material and help students to put forward ideas in written form. This model can create an interesting, fun and meaningful learning atmosphere in learning during the Covid-19 pandemic.

Interesting, fun and meaningful learning is highly recommended in the learning process. In accordance with the characteristics of the guided inquiry learning model, students are required to find their own way of solving a problem that is being faced in the lesson. Science process skills are used to see progress and improve learning outcomes. Science process skills are taught through student worksheets to guide students in systematic and coherent experiments and to link existing concepts and information to the problem at hand. Training science process skills in elementary school students aims to train and familiarize students in every lesson.

The results of this study are in accordance with Bruner's theory (in Jufri, 2017: 26) according to this theory, the learning process will be able to take place actively, creatively, effectively and pleasantly if educators provide opportunities for students to find reasons or concepts, theories and definitions. and so on through examples that illustrate or represent the rules from which they are derived. This shows that Bruner shows an active, creative, effective and fun learning process that can be carried out using a guided inquiry learning process, students build their own knowledge based on the information received through saims process skills. Therefore, learning based on Bruner's theory must use appropriate information so that learning becomes meaningful.

This research is in line with research conducted by Nurhabibah, S., et al. (2018: 1292), there is a significant effect of the application of the guided inquiry learning model on science process skills in grade IV SD. The average value of science process skills learned using the guided inquiry learning model is higher than students who learn through conventional learning. There was a significant effect of the application of the guided inquiry learning model on the cognitive learning outcomes of science content in grade IV SD. The average value of cognitive learning outcomes in science content in students who are taught using guided inquiry learning models is higher than students who learn through conventional learning. 
This research was conducted in normal times before the Covid-19 Pandemic so that learning that emphasizes cognitive is very easy to achieve optimally because students have a high enthusiasm for learning, teachers always motivate students to study harder, and teachers are not too tired. Whereas during the Covid-19 Pandemic, learning was carried out outside of school, students did not have a high enthusiasm for learning, and teachers looked tired because they had to give lessons repeatedly to different groups. Guided inquiry learning compared to conventional learning clearly has different learning outcomes that students get.

Subsequent research is in line with research conducted by Sihaloho, HW, et al. (2018: 94) The results of data analysis in this study using the t test or the one-party average equality test to determine whether students' science process skills (KPS) apply the learning model. Inquiry training is better than conventional learning. The results obtained in the study showed that there were differences in student KPS in the experimental class that applied the inquiry training learning model and the control class using learning.

Subsequent studies that are in line with those proposed by Silaban, A., et al. (2018: 23) state that the guided inquiry learning model is very good to be applied in schools because it can improve science process skills and student understanding. This research also has differences in its application in schools. This research was conducted in class X SMK. Vocational high school students have been trained in various skills and the students' thinking is critical. This is different from what was done in this study, this research was conducted on fifth grade elementary school students who have different attention and treatment because their level of thinking is not critical, they still need guidance by teachers and students' skills are not trained enough.

Based on the results of the research that has been done above, this study has a strong basis for research because it has differences from previous studies. This research has characteristics, namely it was carried out during the Covid-19 Pandemic, carried out outside of school, carried out in groups alternately, the sample used by grade V elementary school students who had their own characteristics, the assessment instrument used observation with 6 achievement indicators, and observations were made every student. Students' science process skills can be achieved if they are taught using guided inquiry learning models instead of using direct instruction learning models.

\subsection{The Effect of Guided Inquiry Learning Model on Higher Level Thinking Ability}

Learning that uses the guided inquiry learning model in the experimental class and the direct instruction learning model in the control class, the average value of the experimental class is higher than the control class (85.74> 64.56). Post-test hypothesis testing on the experimental class and control class using independent samples $t$ test or $t$ test, it is known that there is a significant difference. The calculation results obtained tcount> ttable (3.597> 2.004). This shows that there is a significant influence on the use of guided inquiry learning models on higher-order thinking skills on the theme of heat and its displacement.

The high-level thinking process skills in research have cognitive stages, namely $\mathrm{C} 4$ (analyzing), C5 (evaluating), C6 (creating). Higher order thinking skills are influenced by the guided inquiry learning model because every step taken in guided inquiry can lead students to think critically and creatively so that students are expected to have higher order thinking skills. The results of the study found that students who were taught using guided inquiry learning models had different cognitive levels compared to students who were taught using direct instruction. Students are expected to improve their abilities so that learning outcomes increase. In an effort to foster students' higher order thinking skills, The 
teacher must be able to prepare a lesson plan in the classroom by looking at students' understanding, learning resources, the time it takes in each lesson. The guided inquiry learning model is very suitable to be applied in science learning because students are guided to carry out learning systematically and coherently so that students can improve students' process skills and can improve higher-order thinking skills.

The results of data analysis with the balance test on the post-test of high-order thinking skills in the experimental group and the control group showed that there were differences in the post-test results of higher-order thinking skills between using the guided inquiry learning model using the direct instruction learning model. This is reinforced by the existence of assumptions that underlie the inquiry learning strategy, as stated by Jufri (2017: 72), namely the ability to think at a high level related to data collection and hypotheses contained in the inquiry learning syntax; students benefit from the inquiry learning model being able to communicate, be responsible, and collectively seek knowledge with their group friends; Learning activities with the enthusiasm of finding answers increase student motivation. This is according to the opinion of Kurniawan (2014: 76) which states that guided inquiry is a learning model that emphasizes direct experience for students to find concepts of knowledge. The results showed that students learned through their own experiences. Learning with the guided inquiry learning model makes students more active and students are directly involved in gaining knowledge so that students' higher order thinking skills are higher with guided inquiry learning models than learning with direct instruction learning strategies. Students are finally able to train and develop higher order thinking skills. 76) which states that guided inquiry is a learning model that emphasizes direct experience for students to find concepts of knowledge. The results showed that students learned through their own experiences. Learning with the guided inquiry learning model makes students more active and students are directly involved in acquiring knowledge so that students' higher order thinking skills are higher with guided inquiry learning models than learning with direct instruction learning strategies. Students are finally able to train and develop higher order thinking skills. 76) which states that guided inquiry is a learning model that emphasizes direct experience for students to find concepts of knowledge. The results showed that students learned through their own experiences. Learning with the guided inquiry learning model makes students more active and students are directly involved in acquiring knowledge so that students' higher order thinking skills are higher with guided inquiry learning models than learning with direct instruction learning strategies. Students are finally able to train and develop higher order thinking skills. Learning with the guided inquiry learning model makes students more active and students are directly involved in gaining knowledge so that students' higher order thinking skills are higher with guided inquiry learning models than learning with direct instruction learning strategies. Students are finally able to train and develop higher order thinking skills. Learning with the guided inquiry learning model makes students more active and students are directly involved in gaining knowledge so that students' higher order thinking skills are higher with guided inquiry learning models than learning with direct instruction learning strategies. Students are finally able to train and develop higher order thinking skills.

This research is not in accordance with the research conducted by Manalu, A. (2019: 95) that students in the high group and students in the middle group fulfill two KBTT indicators, namely indicator 1 (analyzing incoming information and sharing information or structuring information into sections which is smaller to recognize patterns or relationships) and indicator 2 (able to recognize and distinguish the causes and effects of a complex scenario). Meanwhile, students in the low category cannot fulfill all KBTT 
indicators. Based on research findings and research results, it can be concluded that students' high-order thinking skills are very important during the learning process. This is not in line with the findings made that there is no effect on higher-order thinking skills. This research only explains the achievement that students produce in learning

Based on the description above, it can be concluded that the guided inquiry learning model is better to be applied in learning compared to the direct instruction learning model to produce higher-order thinking skills. This is based on the findings or research results that the high-order thinking skills of students who are taught using guided inquiry are higher than the direct instruction model.

\section{Conclusion}

Based on the discussion of the research results, it can be concluded that the average value of science process skills in the guided inquiry class is 81.62 and the direct instruction learning model class is 79.02. A significant influence on students' science process skills in the learning process on the theme of heat and its displacement, with a score of tcount (2.384) $>$ ttable (2.004) for $\mathrm{n}=56, \alpha=0.05$ and sig. 2 tailed $(0.021)<\alpha=0.05$, so that $\mathrm{H}_{0}$ rejected. then $\mathrm{H} 0$ is rejected and $\mathrm{H} 1$ is accepted. This suggests that the use of guided inquiry learning models has an effect on the improvement of students' science process skills on the theme of heat and its transfer in grade V SD Negeri 104260 Melati. Through testing the hypothesis that the science process skills using the guided inquiry learning model are higher than using the direct instruction learning model on the theme of heat and its displacement in grade V SD Negeri 104260 Melati. There is an effect of the guided inquiry learning model on science process skills. This influence can be seen in the increase in the ability to process science during learning activities.

The average value of high-order thinking skills in the guided inquiry class is 75.57 and in the class of direct instruction learning model. A total of 67.43. Through testing the hypothesis that high-order thinking skills using guided inquiry learning models are higher than using direct instruction learning models on the theme of heat and its displacement in grade V SD Negeri 104260 Melati. There is an effect of the guided inquiry learning model on science process skills. This influence can be seen in the increase in the ability to process science during learning activities. A significant influence on students' high-order thinking skills in the learning process on the theme of heat and its displacement, with the results of the analysis of high-order thinking skills has a tcount (3.597) $>\mathrm{t}$ table (2.004) for $\mathrm{n}=56, \alpha$ $=0.05$ and sig. 2 tailed $(0.001)<\alpha=0.05$, so that $\mathrm{H}_{0}$ rejected and Ha accepted. This suggests that the use of the guided inquiry learning model has an effect on the improvement of students' higher order thinking skills on the theme of heat and the transfer of grade V SD Negeri 104260 Melati.

\section{References}

Hamdayana, J. (2017). Model dan Metode Pembelajaran Kreatif dan Berkarakter. Ghalia Indonesia: Bogor.

Jufri, A.W. (2017). Belajar dan Pembelajaran Sains. Pustaka Reka Cipta. Bandung.

Kemendikbud. (2012). Pengembangan Kurikulum 2013. Jakarta: Kemendikbud.

Kementerian Pendidikan dan Kebudayaan Direktorat Jenderal Pendidikan Dasar dan Menengah. (2014). Direktorat Pembinaan Sekolah Dasar tentang Panduan Penilaian untuk Sekolah Dasar. 
Kuncoro, R.Y., Triyanto, Triastuti, R. (2020). Constraints in the Implementation of Digital Ethics in SMA Muhammadiyah 1 Surakarta. Budapest International Research and Critics in Linguistics and Education (BirLE) Journal Vol 3 (1): 157-163.

Kurniawan, D. (2014). Pembelajaran Tematik Terpadu, Alfabeta. Bandung.

Manalu, A. (2019). Pengaruh Model Pembelajaran Inkuiri Terbimbing (Guided Inquiry) Terhadap Higher Order Of Thinking Skills (Hots). Jurnal Inovasi Pembelajaran Fisika (INPAFI). 7 (3) :91-96.

Mindayani, N., Hadi, W., and Ambarita, B. (2019). The Development of SOLO Taxonomy Based Assessment Tool on Text of Observation Reports of X Grade Students of Senior High School 1 NA. IX-X. Budapest International Research and Critics in Linguistics and Education (BirLE) Journal Vol 2 (4): 371-381.

Neolaka, A. and Neolaka, G.A.A. (2017). Landasan Pendidikan Dasar Pengenala Diri Sendiri Menuju Perubahan Hidup. Kencana. Depok.

Nurdyansyah, and Fahyuni, E.F. (2016). Inovasi Model Pembelajaran, Nazamia Learning Center. Sidoarjo.

Nurhabibah, S. (2018). Pengaruh Model Pembelajaran Inkuiri Terbimbing Terhadap Keterampilan Proses Sains dan Hasil Belajar Muatan IPA di Kelas IV. Jurnal Pendidikan. 3(10):1286-1293.

Sihaloho, H.W., Sahyar, and Simanjuntak, M. P. (2018). Pengaruh Model Pembelajaran Inquiry Training Terhadap Keterampilan Proses Sains. Jurnal Pendidikan Fisika. 7(2):91-97.

Sofyan, F. A. (2019). Implementasi HOTS pada Kurikulum 2013. Jurnal Inventa. 3(1): 117.

Susanto, A. (2016). Teori Belajar \& Pembelajaran di Sekolah Dasar. Kencana. Jakarta.

Tawil, M., and Liliasari (2014). Keterampilan-Keterampilan Sains dan Implementasinya dalam Pembelajaran IPA. Badan Penerbit UNM. Makasar.

Trianto. (2010). Mendesain Pembelajaran Inovatf-Progesif. Kencana. Jakarta

Waluyandi, F., Trihastuti, R., and Muchtarom, M. (2020). Implementation of Parental Involvement in Learning Civic Education. Budapest International Research and Critics in Linguistics and Education (BirLE) Journal Vol 3 (4): 1686-1695.

Yani. A. (2019). Cara Mudah Menulis Soal HOTS. Refika Aditama. Bandung. 